\title{
Development and Evaluation of a Combined Castor Seed Roaster- Oil Expeller
}

Balogun, Abdu-Lateef ${ }^{1}$, Jekayinfa, S. O ${ }^{2}$., Olajide, J. O ${ }^{3}$., Ola, F. A ${ }^{2 *}$. and Ogunlade, C. A .

1. Department of Agricultural Engineering, Kwara State Polytechnic, Ilorin, Nigeria

2. Department of Agricultural Engineering, Ladoke Akintola University of Technology, Ogbomoso, Nigeria

3. Department of Food Engineering, Ladoke Akintola University of Technology, Ogbomoso, Nigeria.

4. Department of Agricultural \& Biosystem Engineering, Adeleke University Ede, Osun State, Nigeria

* Corresponding Author. faola@lautech.edu.ng

\begin{abstract}
This study evaluated optimal process parameters for mechanical oil expression from castor seeds after designing a castor seed roaster-expeller. The effect of input variables (Moisture Content at 6, 7, 8, 9 and 10\% db; Roasting Temperature at $80,90,100,110$ and $120^{\circ} \mathrm{C}$ and Applied Pressure at 15, 20, 25, 30 and $35 \mathrm{MPa}$ ) on the oil yield, expression efficiency, expression loss and energy used were determined using Central Composite Design in Response Surface Methodology for the optimization and modelling. Analysis of Variance was employed to determine the level of significance $(\mathrm{P} \leq 0.05)$. The optimum expression efficiency, expression loss and minimum energy used were $72.86 \%, 0.63 \%$ and 584.19 Watts obtained at experimental conditions of $15.00 \mathrm{MPa}$ applied pressure, $6 \%$ moisture content and $85.52^{\circ} \mathrm{C}$ heating temperature respectively. The $R^{2}$ values of the developed models ranged from 0.813 to 0.982 at $95 \%$ confidence level. The developed combined castor seed roaster-oil expeller was found to be efficient and developed models showed adequate prediction with good relationships between dependent and independent variables.
\end{abstract}

Keywords: castor seed, oil extraction, modeling, optimization

DOI: $10.7176 /$ ISDE/11-1-07

Publication date: January $31^{\text {st }} 2020$

\section{Introduction}

Castor seed (Ricinus communis L.) is large plant, grown throughout the tropics and believed to be a native of Africa particularly Nigeria where all the species are found [1]. Today, India and Brazil are the largest producers of castor seeds and castor oil, while USA and UK are major buyers. The castor oil plant is grown commercially for pharmaceutical and industrial uses of its oil ${ }_{[1]}$. It is used in the production of synthetic resins, plastics, fibres, paints, vanishes and various chemicals including drying oils and plasticizers. In addition to these, castor oil and its constituent are used in superficial enhancement, hair oil, fungi static (fungus-growth inhibiting) compounds, printing inks, embalming fluid, soap, fat liquor, grease dying and, hydraulic fluids and textile finishing materials. It is essential to harness the commercial potentials in castor oil because of its numerous economic values; this is possible with the development of an expeller to boost the oil production from castor seeds in Nigeria. Though a number of uses for castor oil have been spelt out, little knowledge is available on castor oil expression. Previous researchers have expressed castor oil by using manual methods such as hand press, ghanis, water extraction and manual pressing which resulted in minimal oil recovery and more labour requirement

Oil expression process, when carried out manually, is energy and time consuming, tedious and of low oil recovery [2]. [3] extensively reviewed the technologies involved in the expression of oil from oil-bearing seeds and confirmed the above short comings of the manual methods. Thus, there is the need to mechanize oil expression to reduce the drudgery involved in the manual means of expressing the oil bearing seeds however; expellers are the best choice of technology for expression of oil from oilseeds [4, 2]. From the foregoing, the development of a mechanical oil expeller for castor seed becomes highly desirable. Also, heat application in pre-treating oil bearing seeds is very essential to improve the yield of oil [5]. The traditional roasting of castor seed produces uneven roasted seeds due to the unavailability of accurate temperature control and monitoring system, apart from exposing the castor to unfavourable conditions. It is a tedious process involving hand stirring and exposure to heat [6]. However, a small-scale combined roaster-oil expeller will no doubt be a suitable substitute to manual means of expressing vegetable oil by combining two unit operations into one to reduce cost, time and energy expended and improves overall expression efficiency. There is the need to mechanize oil expression and also optimize energy input to 
reduce the drudgery involved in the traditional means of extracting the oil bearing seed. However, there is little or no literature on process optimization of castor seeds oil expression using combined castor seed roaster and oil expeller. Therefore, this study designed a combined roaster-expeller for castor seeds and evaluated the machine by investigating appropriate processing parameters (moisture content, roasting temperature and applied pressure) for optimized machine performance.

\section{Materials and Methods}

\subsection{Sample Procurement and Preparation}

Big white size variety of Ricinus communis seeds were obtained from a produce merchant at Oja-igbo market in Ogbomoso, Oyo State, Nigeria, they were confirmed from Agronomy Department, Ladoke Akintola University of Technology, Ogbomoso, Nigeria. The castor seed samples were divided into fifteen equal parts and conditioned by adding a calculated quantity of water required to obtain the desired moisture contents. The added moisture was allowed to equilibrate by placing the conditioned seeds in a refrigerator for $48 \mathrm{~h}$ after which the moisture content was determined using a moisture analyzer. Calculated quantity of water was obtained from Equation 1 [2].

$$
Q=\frac{A(b-a)}{(100-b)}
$$

Where: A is the Initial mass of the sample $(\mathrm{kg}), \mathrm{a}$ is the Initial moisture content of the sample (\% wet basis $(\mathrm{db}))$, $\mathrm{b}$ is the Final (desired) moisture content of sample (\% wet basis ( $\mathrm{db})$ ) and Q is the Mass of water to be added( $\mathrm{kg})$. 2.2 Design Consideration

In order to ensure a high level of efficiency, functionality and reliability, a combined castor roaster- expeller was designed using locally available materials. The ease of maintenance and repair and cost of components, power consumption and ergonomics were considered.

2.3 Design Analysis:

i. Roasting chamber:- The heating chamber was designed to contain $1 \mathrm{~kg}$ of castor seed having a bulk density, $\rho$ of $494.57 \mathrm{kgm}^{-3}$. The volume of the heating chamber was obtained using Equation 2:-

$$
\text { volume, } V_{c}=\frac{m}{\rho}
$$

Where: $m$ is the mass of castor seed $(1 \mathrm{~kg})$, Pis the density of castor $\left(494.57 \mathrm{~kg} / \mathrm{m}^{3}\right)$

The volume of the cylindrical roasting chamber is given by Equation 3:-

$$
\mathrm{V}_{\mathrm{c}}=\pi \times \mathrm{r}^{2} \times \mathrm{h}
$$

Where: $\mathrm{r}$ is the radius $(0.065 \mathrm{~m})$, and $\mathrm{h}$ is the height $(0.15 \mathrm{~m})$

ii. Determination of roaster volume:- this was obtained from the area of cross-section of the cylinder (A) using Equations 4:-

$$
\begin{aligned}
& \mathrm{A}=2 \pi r^{2}+2 \pi r h \\
& \mathrm{~V}_{\mathrm{R}}=\pi \times \mathrm{r}^{2} \times \mathrm{h}
\end{aligned}
$$

Where: $V_{R}$ is the roaster volume $\left(\mathrm{m}^{3}\right)$

The value for the height was assumed based on the capacity to be handled per batch which was obtained using Equation 5:-

$$
\text { Capacity of roaster }=0.0027 \mathrm{~m}^{3} / \mathrm{h}
$$

Thus, in one revolution, the worm expeller will handle $\frac{0.0027}{60}=0.0000454 \mathrm{~m}^{3} / \mathrm{min} / \mathrm{rev}$

iii. Determination of heater capacity:- the heat flow through a single wall of a cylinder is given by Fourier's law of conduction using Equation 6 [7].

$$
\mathrm{Q}_{\text {cond }}=\frac{\left(\mathrm{t}_{1}-\mathrm{t}_{2}\right)}{\frac{\operatorname{In}\left({ }^{\left.\mathrm{r}_{2} / \mathrm{r}_{1}\right)}\right.}{2 \pi \mathrm{k}}}
$$

Where:- $Q_{\text {cond }}$ is the heat flow from the heating element to the roaster chamber by conduction, $(\mathrm{W}), \mathrm{t}_{1}$ is the outside surface temperature of the roaster $\left({ }^{\circ} \mathrm{C}\right), t_{2}$ is the inner surface temperature of the roaster $\left({ }^{\circ} \mathrm{C}\right), r_{1}$ is the outer radius of the roaster $(\mathrm{m}), \mathrm{r}_{2}$ is the inner radius of the roaster $(\mathrm{m}), \mathrm{K}$ is the thermal conductivity of the stainless material and $\mathrm{L}$ is the thickness of the stainless material.

$i v$. Analysis of heat transfer rate from the heater to the roaster:- Treating the castor seed as fluid flow over a solid surface and considering the heat transfer from the roaster to the castor seed by convection as given in Equation 7 $[7]:-$

$$
Q_{\text {conv }}=h_{c} A\left(t_{s}-t_{f}\right)
$$

Where: $\mathrm{Q}_{\mathrm{conv}}$ is heat transfer from the roaster to the castor seed by convection $(55.47 \mathrm{~W})$, $\mathrm{t}_{\mathrm{f}}$ is Fluid temperature, $\left({ }^{\circ} \mathrm{C}\right), \mathrm{t}_{\mathrm{s}}$ is Solid surface temperature, $\left({ }^{\circ} \mathrm{C}\right)$, Ais Area of the roasting chamber $\left(\mathrm{m}^{2}\right), h_{c}$ is convection heat transfer 
coefficient $\left(\mathrm{W} / \mathrm{m}^{2} \mathrm{~K}\right)$

v. Design of expeller hopper:- Hopper design was based on the criterion of the angle of repose which is the maximum slope at which a heap of any loose or fragmented bulk material will stand without sliding [8 ]. It is also the angle of friction at rest 9(Eugene and Theodore, 1996). The hopper uses the gravity discharge mechanism with the recommended angle for agricultural materials being $8^{\circ}$ to $10^{\circ}$ higher than their angle of repose [8]. Volume of hopper $\left(\mathrm{V}_{\mathrm{H}}\right)$ was determined using the formula given by [10]. The hopper was taken as a frustum of a pyramid and the volume was calculated using Equation 8:-

$$
\text { Volume of Pyramid }=\frac{1}{3} \pi\left[\mathrm{R}^{2} \mathrm{H}-\mathrm{r}^{2} \mathrm{~h}\right]
$$

Where: $\mathrm{R}$ is outer radius of hopper $(90 \mathrm{~mm}), \mathrm{H}$ is external height $(117.19 \mathrm{~mm}), \mathrm{r}$ is internal radius of hopper $(36.7$ $\mathrm{mm})$, $\mathrm{h}$ is internal height of hopper (20.42 $\mathrm{mm})$,

vi. Power required for moving and rotating the screw shaft:- The power required for continuous moving and rotating the screw shaft was estimated using Equation $9[10]$.

$$
\mathrm{P}=\frac{2 \pi \mathrm{nT}}{60}
$$

While the torque developed can be obtained using Equation 10:-

$$
T=\mathrm{Fr}
$$

Where: $\mathrm{F}$ is weight of screw shaft $(6.6 \mathrm{~kg} \times 9.81=64.75 \mathrm{~N}), \mathrm{n}$ is speed of screw shaft $(50 \mathrm{rpm})$ and $\mathrm{r}$ is radius of screw shaft (18.25 mm i.e. $0.01825 \mathrm{~m})$

vii. Power required for crushing castor seeds in the press barrel $\left(P_{c}\right)$ :- The power required for castor seed crushing was estimated using Equation $11[10]$ :

$$
\mathrm{P}=\frac{\mathrm{FD}}{\mathrm{t}}
$$

Where: $\mathrm{F}$ is the force $(\mathrm{N}), \mathrm{D}$ is the distance $(\mathrm{m})$ and $\mathrm{t}$ is the time taken $(\mathrm{s})$

$$
P_{c}=\frac{R_{f} D_{g}}{t}
$$

Where: $R_{f}$ is the rupture force of castor, $D_{g}$ is the average geometric mean diameter $(\mathrm{mm}), t$ is the unit time viii. Determination of belt speed:- The expeller power transmission system was basically through V-belt drives because it can drives shafts from a single drive without the use of belt tightness [12 ]. Equation (13) was used to obtain the speed of belt $[10]:-$

$$
\mathrm{V}_{\mathrm{b}}=\frac{\pi \mathrm{dN}}{60}
$$

Where: $V_{b}$ is the speed of belt $(0.51 \mathrm{~m} / \mathrm{s}), \mathrm{d}$ is diameter of driven pulley $(0.195 \mathrm{~m})$ and $\mathrm{N}$ is the speed of the pulley (50 rpm).

ix. Determination of angle of wrap:- Equation (14) was used to determine the angle of wrap

$$
\theta=\left[180-2 \sin ^{-1}\left(\frac{D-d}{2 C}\right)\right] \frac{\pi}{180}
$$

Where: $\Theta$ is the angle of wrap (rad), $\mathrm{D}$ is the diameter of the driving pulley $(195 \mathrm{~mm})$ and $\mathrm{d}$ is the diameter of driven pulley $(75 \mathrm{~mm})$.

$x$. Determination of belt tension:- the tension on the tight and slack side was obtained using Equation 15 [10 ]

$$
\mathrm{P}=\left(\mathrm{T}_{1}-\mathrm{T}_{2}\right) \mathrm{V}
$$

Where: $\mathrm{P}$ is the design power (Watt), $\mathrm{T}_{1}$ and $\mathrm{T}_{2}$ are belt tensions at tight side and slack side (Newton) respectively and $\mathrm{V}$ is the speed of belt $(\mathrm{m} / \mathrm{s})$. At maximum power condition, maximum tension, $\mathrm{T}$ was obtained using Equation 16:

$$
\mathrm{T}_{1}=\frac{2 \mathrm{~T}}{3}
$$

xi. Determination of belt length:- To determine the length of belt, Eqn. 17 given by [10 ]was used.

$$
\mathrm{L}=2 \mathrm{C}+1.57\left(\mathrm{D}_{1}+\mathrm{D}_{2}\right)+\frac{\left(\mathrm{D}_{1}-\mathrm{D}_{2}\right)^{2}}{4 \mathrm{C}}
$$

Where: $L$ is length of belt $(\mathrm{m}), C$ is the center to center distance of the driver to driven pulley $(\mathrm{m}), D_{l}$ is the diameter of driven pulley $(\mathrm{m}), D_{2}$ is the diameter of driver pulley $(\mathrm{m})$.

xii. Determination of center distance, between pulleys of the expeller shaft and the electric motor:- The expeller center distance was calculated following the procedure prescribed by [10 ] in Equation 18:-

$$
\mathrm{C}=\frac{1}{2}\left(\mathrm{D}_{1}+\mathrm{D}_{2}\right)+\mathrm{D}_{1}
$$

xiii. Design of expeller shaft diameter:- The expeller shaft diameter was designed using the relationship given by $[10]$ in Equations 19 and 20:- 


$$
\begin{aligned}
& \mathrm{T}=\frac{60}{2 \pi \mathrm{N}}=\mathrm{T}_{\mathrm{e}}=\frac{\pi \tau \mathrm{d}^{3}}{16} \\
& \mathrm{~d}^{3}=\frac{(60 \mathrm{P})}{2 \pi^{2} \tau \mathrm{N}}
\end{aligned}
$$

Where: $\mathrm{T}_{\mathrm{e}}=\mathrm{T}$ and equal to torque under shaft shear equation $(\mathrm{Nm}), \mathrm{N}$ is the Worm shaft speed in (rpm), $\mathrm{T}_{\mathrm{e}}$ is the Equivalent twisting moment $(\mathrm{Nm}), \mathrm{d}$ is the Shaft diameter $(35 \mathrm{~m})$ and $\tau$ is the Allowable shear stress $\left(\mathrm{N} / \mathrm{mm}^{2}\right)$.

\subsection{Machine Description}

The combined roaster oil expeller consists of the roaster, heating element, roaster motor, stirrer, expeller hopper, worm shaft, barrel, male cone, female cone, main frame, oil outlet, cake outlet, pulley, prime mover seat, thermocouple and pressure transducer. The seeds are introduced into the machine through the roasting chamber where they are heated and flows down to the expeller hopper through a sliding gate provided on the roasting chamber. The expeller has a tapered shaft with equal pitch. The pitch of the screw flights gradually decreases towards the discharge end, to increase the pressure on the material as it is carried through the barrel. Figure 1shows the isometric design of the combined castor roaster oil expeller while the sectional and orthographic view is presented in Figure 2:-

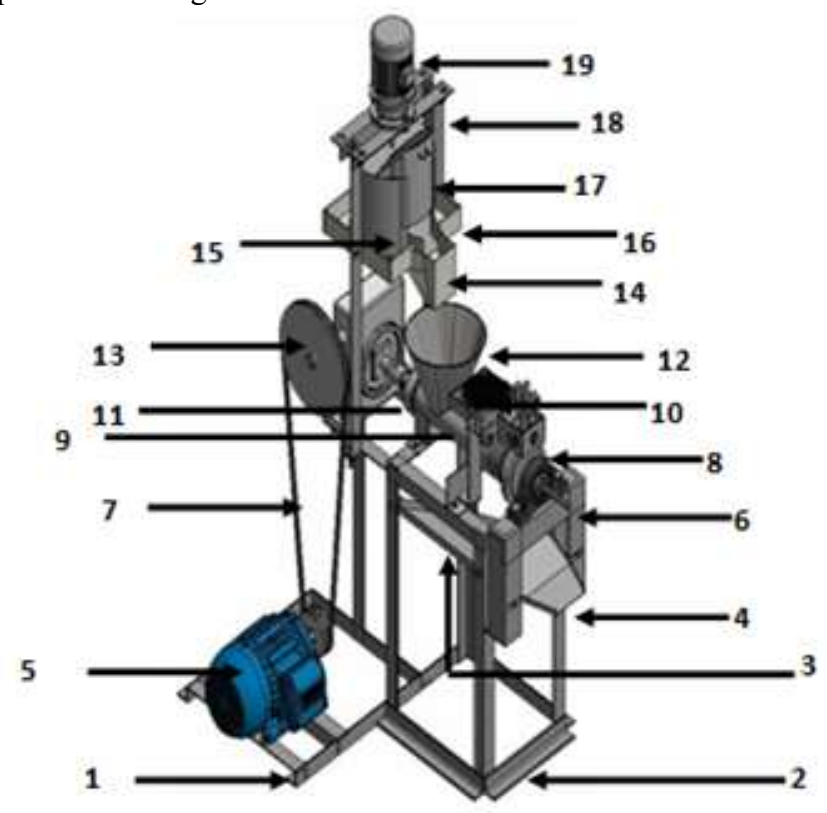

\begin{tabular}{|l|l|}
\hline Parts List & \\
\hline Item & Part Number \\
\hline 1 & Expeller motor base \\
\hline 2 & Expeller main frame \\
\hline 3 & Oil outlet \\
\hline 4 & Cake outlet \\
\hline 5 & Eloctric motor \\
\hline 6 & Worm shaft \\
\hline 7 & Balt \\
\hline 8 & Pillow Bearing \\
\hline 9 & Expeller Barrel \\
\hline 10 & Pressure pange \\
\hline 11 & Gear box \\
\hline 12 & Hopper \\
\hline 13 & Pulloy \\
\hline 14 & Rosstar Outh \\
\hline 15 & Rosster \\
\hline 16 & Roastar and Hoating Eloment Base \\
\hline 17 & Roaster Inlet \\
\hline 18 & Rosster Frame \\
\hline 19 & Roaster Eloctric Motor \\
\hline
\end{tabular}

Figure 1. Isometric Design of the Combined Castor Seeds Roaster-Oil Expeller 


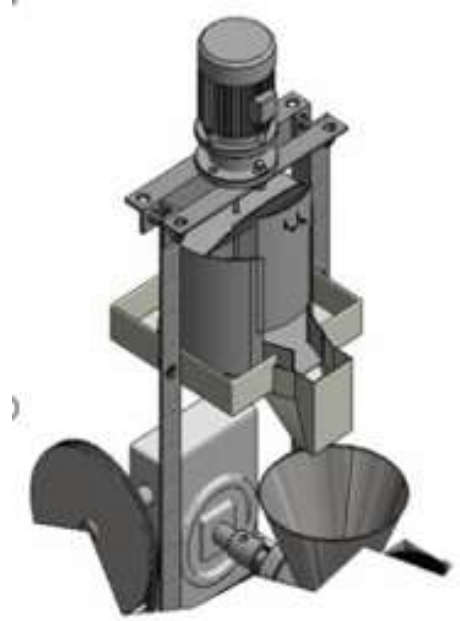

DETAIL A

SCALE $0.2: 1$

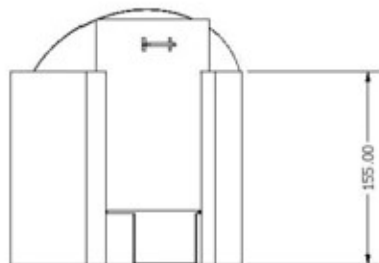

FRONT VIEW

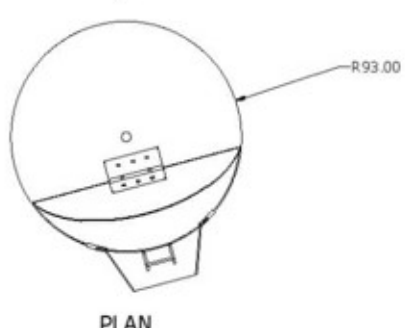

PLAN

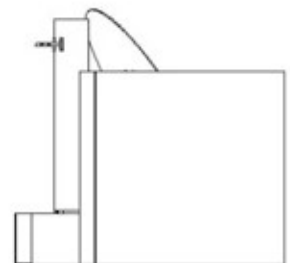

SIDE VIEW

Figure 2. Sectional and Orthographic View of the Roaster

2.5 Bill of Engineering Measurement and Evaluation (BEME) of Production

Table 1 shows the various materials used for machine construction, their specifications and quantities. This combined roaster-expeller is economically viable because locally sourced materials were carefully selected and used for the fabrication of the machine.

Table 1: Bill of engineering measurement and evaluation for the combined castor seed roaster-expeller

\begin{tabular}{|c|c|c|c|c|}
\hline $\mathrm{S} / \mathrm{N}$ & Material specification & Quantity & Rate $(\mathrm{N})$ & Amount $(\mathrm{N})$ \\
\hline 1. & Conveyor screw & 1 & $45,000.00$ & $45,000.00$ \\
\hline 2. & Mild steel pipe & 1 & $8,500.00$ & $8,500.00$ \\
\hline 3. & $1.5 \mathrm{~mm}$ mild steel sheet & & & $1,500.00$ \\
\hline 4. & Reduction gear box & 1 & $30,000.00$ & $30,000.00$ \\
\hline 5. & $3 \mathrm{Hp}$ single phase electric motor & 1 & $35,000.00$ & $35,000.00$ \\
\hline 6. & $50 \times 50 \times 4 \mathrm{~mm}$ 'L' iron & $2 \frac{1}{2}$ & $5,000.00$ & $12,500.00$ \\
\hline 7. & Machining & & & $70,000.00$ \\
\hline 8. & G 12 electrode & 1 pack & $2,500.00$ & $2,500.00$ \\
\hline 9. & 1Hp Reduction gear motor & 1 & $10,000.00$ & $10,000.00$ \\
\hline 10. & Cutting disc & 1 & 700 & 700 \\
\hline 11. & Grinding disc & 1 & 500 & 500 \\
\hline 12. & $3 \mathrm{~mm}$ stainless sheet & $1 / 4$ & $70,000.00$ & $17,500.00$ \\
\hline 13. & Heating element & 1 & 800 & 800 \\
\hline 14. & M10 Bolt \& nut & $2 \frac{1}{2}$ dozen & 400 & $1,000.00$ \\
\hline 15. & Painting & & & $7,500.00$ \\
\hline 16. & Workmanship & & & $25,000.00$ \\
\hline \multirow[t]{2}{*}{17.} & Transportation & & & $5,000.00$ \\
\hline & Total & & & $\begin{array}{l}\text { N273,000.00 } \\
\text { (600 USD) }\end{array}$ \\
\hline
\end{tabular}

\subsection{Performance Evaluation}

i. Oil yield:- this was obtained as the ratio of mass of oil expressed to the total mass of sample before expression as presented in Equation 21 [4]

$$
\mathrm{OY}=\frac{\mathrm{M}_{\text {Oil }}}{\mathrm{M}_{\text {Seed }}} \times 100
$$

Where: OY is oil yield (\%), $\mathrm{M}_{\mathrm{oil}}$ is the mass of oil expressed $(\mathrm{g})$ and $\mathrm{M}_{\text {seed }}$ is the mass of seed $(\mathrm{g})$

ii. Expression efficiency:- this was determined as ratio of the mass of oil expressed to the total mass of oil resident in the castor sample before expression as shown in Equation 22 [12 ] 


$$
\mathrm{E}_{\mathrm{E}}=\frac{\mathrm{M}_{\mathrm{Oil}}}{\mathrm{XM}_{\text {Seed }}} \times 100
$$

Where: $\mathrm{X}$ is the maximum oil content resident in castor seeds, obtained from the use soxhlet oil extractor as 0.45 iii. Expression loss:- this was determined as the difference between the mass of the sample before expression and the sum total of the mass of oil expressed and residual cake after expression divided by the mass of the sample before expression. It was mathematically obtained using Equation 23 [12 ]

$$
\mathrm{E}_{\mathrm{L}}=\left[\frac{\mathrm{M}_{\text {Seed }}-\left(\mathrm{M}_{\text {Cake }}+\mathrm{M}_{\text {Oil }}\right)}{\mathrm{M}_{\text {Seed }}}\right] \times 100
$$

Where:- $\mathrm{M}_{\text {Cake }}$ is the Mass of cake ( $\mathrm{g}$ )

iv. Energy used for oil expression:- A digital voltmeter ammeter 4 in 1; voltage, current, power and energy with closed CT (model no: PZEM - 061) was used to obtained the total energy of the combined castor roaster oil expeller for each oil expression treatment combinations.

\subsection{Data Analysis and Validation of Model}

In order to correlate the findings from this study, Mathematical models predicting relationship between independent and dependent variables were developed using multiple linear regression at $95 \%$ level of confidence. The authenticity of the models was obtained using the $R^{2}$ and probability of prediction $F$ ratio test and statistical analysis software Design Expert Version 10.0.1. The models were validated by comparing experimental results with calculated results using the models; Analysis of Variance (ANOVA) was used to determine significance and fitness of each equation and interactions of responses and variables.

\subsection{Results and Discussion}

The effect of operating parameters (applied pressure, moisture content and roasting temperature) on the oil yield, expression efficiency, expression loss and energy is presented in Table 2.

\subsection{Effect of Operating Parameters on Oil Yield}

The regression analysis gives a F-value of 81.82 and p-value of the terms $\mathrm{B}(0.0001), \mathrm{C}(0.0001), \mathrm{B}^{2}(0.0091), \mathrm{AC}$ (0.0348), BC (0.0039) which shows that the model terms are significant at $\mathrm{p} \leq 0.05$ while $\mathrm{A}$ and $\mathrm{C}^{2}$ terms are not significant with P-value above 0.05 (Table 3). It was observed that B (moisture content) has the highest influence in the regression model with F-value of 431.65 followed by $\mathrm{C}$ (roasting temperature) with F-value of 90.68 also, B plays a significant role in the developed model followed by $\mathrm{C}$. The significance of the model developed was tested by the $R^{2}$ and $A d j . R^{2}$ value. The obtained $R^{2}, A d j . R^{2}$, and Pred. $R^{2}$ are $0.9795,0.9675$ and 0.9060 , respectively. The fitness of a model was determined by the $R^{2}$ value which is more than 0.80 which is in accordance with the recommendation of [13 ]. Also since the $R^{2}$ and the $A d j . R^{2}$ are close to 1 which implies that the model fits the data well. The model equation predicting the oil yield is presented in Equation 24.

$$
\begin{gathered}
Y_{1}=73.693-0.250 \mathrm{~A}+18.847 \mathrm{~B}+0.834 \mathrm{C}+0.928 \mathrm{~B}^{2}-5.716 \mathrm{E}-003 \mathrm{C}^{2}+ \\
2.500 \mathrm{E}-003 \mathrm{AC}+0.019 \mathrm{BC} \text { Where:- } Y_{l} \text { is the oil yield }(\%), A \text { is the Applied pressure }(\mathrm{MPa}), B \text { is } \\
\text { the Moisture content }(\%) \text { and } C \text { is the } \\
\text { Roasting Temperature }\left({ }^{\circ} \mathrm{C}\right)
\end{gathered}
$$


Table 2: Experimental data obtained for oil yield, expression efficiency, expression loss and energy used

\begin{tabular}{llllllll}
\hline Run & $\begin{array}{l}\text { Applied } \\
\text { Pressure } \\
(\mathbf{M P a})\end{array}$ & $\begin{array}{l}\text { Moisture } \\
\text { Content } \\
\mathbf{( \% )}\end{array}$ & $\begin{array}{l}\text { Roasting } \\
\text { temperature } \\
(\mathbf{(} \mathbf{C})\end{array}$ & $\begin{array}{l}\text { Oil } \\
\text { Yield } \\
\mathbf{( \% )}\end{array}$ & $\begin{array}{l}\text { Expression } \\
\text { efficiency } \\
\mathbf{( \% )}\end{array}$ & $\begin{array}{l}\text { Expression } \\
\text { loss } \\
\mathbf{( \% )}\end{array}$ & $\begin{array}{l}\text { Energy } \\
\text { Use } \\
(\mathbf{W})\end{array}$ \\
\hline 1 & 35 & 10 & 80 & 22 & 48.8 & 7.7 & 776 \\
2 & 25 & 8 & 100 & 24 & 53.3 & 5.6 & 645 \\
3 & 15 & 10 & 120 & 19 & 42.2 & 9.5 & 604 \\
4 & 15 & 6 & 120 & 26 & 57.7 & 4.6 & 600 \\
5 & 25 & 8 & 100 & 24 & 53.3 & 5.6 & 645 \\
6 & 25 & 7 & 100 & 26 & 57.7 & 4.6 & 640 \\
7 & 25 & 8 & 100 & 24 & 53.3 & 5.6 & 645 \\
8 & 15 & 10 & 80 & 22 & 48.8 & 7.7 & 604 \\
9 & 25 & 8 & 100 & 24 & 53.3 & 5.6 & 645 \\
10 & 30 & 8 & 100 & 23 & 51.1 & 0.7 & 652 \\
11 & 25 & 8 & 100 & 24 & 53.3 & 5.6 & 645 \\
12 & 35 & 6 & 120 & 27 & 60 & 4.1 & 720 \\
13 & 35 & 6 & 80 & 31 & 68.8 & 3.8 & 720 \\
14 & 25 & 8 & 110 & 22 & 48.8 & 7.7 & 645 \\
15 & 15 & 6 & 80 & 33 & 73.3 & 2.9 & 600 \\
16 & 25 & 8 & 100 & 24 & 53.3 & 5.6 & 645 \\
17 & 25 & 9 & 100 & 22 & 48.8 & 7.7 & 604 \\
18 & 25 & 8 & 90 & 23 & 51.1 & 6.3 & 645 \\
19 & 20 & 8 & 100 & 23 & 51.1 & 6.3 & 632 \\
20 & 35 & 10 & 120 & 20 & 44.4 & 8.6 & 776 \\
\hline
\end{tabular}

There was a slight increase in oil recovery when the applied pressure was increased from 15 to $35 \mathrm{MPa}$ for all the treatment combinations while at a high roasting temperature, the oil recovery reduces (Figure 3 ). The phenomenon could be attributed to the fact that water evaporates faster at a higher temperature causing substantial moisture loss; the compressed cake becomes hard and dried thus reducing the oil flow. When an oilseed is subjected to heat treatment, moisture loss creates a void which serves as migratory space for the contents of the oil-bearing cells thereby facilitating the rupture of oil-bearing cells as heating progresses [14 ]. Also, this lowers the viscosity of the oil and coagulates the protein, thus enabling oil to emerge from the oil-bearing cells into the surface [15 ].
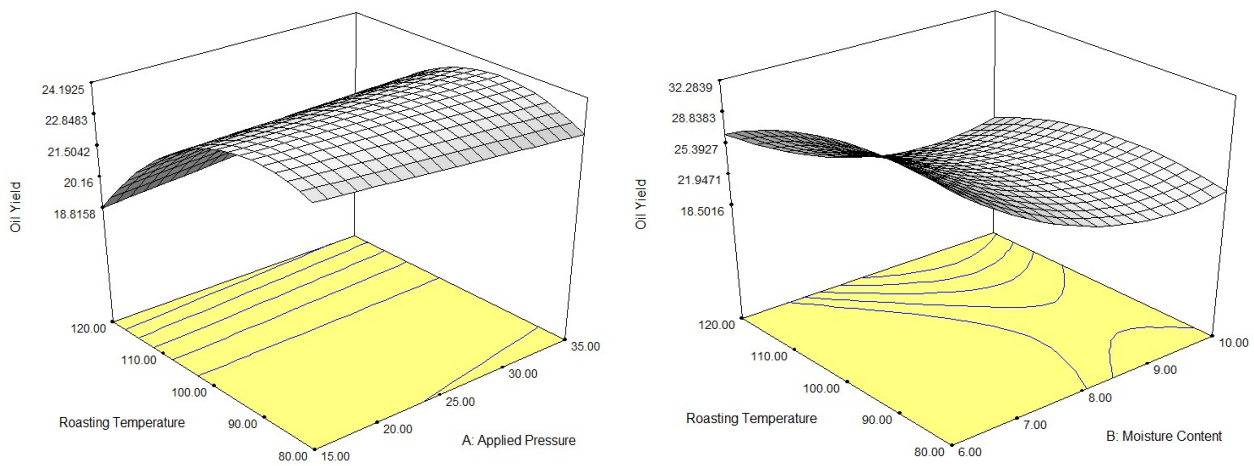

Figure 3. Response surface plot showing the effect of operating parameters on the oil yield

Similar observation was made by [16] while pressing groundnuts and a more predominant temperature and pressure interaction at higher levels of these factors were observed. Such an interaction may be understood from the fact that increasing temperature decreases the viscosity of the flowing oil and thereby increases its flow ability through 
compressed medium while an increase in applied pressure increases the viscosity and reduces the flow ability. This observation is in agreement with findings of [17].Also, according to [18] increasing the pressure applied to oil seeds during screw pressing operation narrows shears and may eventually seal the capillaries through which oil is squeezed out. It is therefore advisable to identify the optimum expression pressures for oilseeds because higher pressures do not necessarily improve yield and expression efficiency, thereby increasing cost. Similarly, the highest oil yields were obtained at roasting temperature of $110^{\circ} \mathrm{C}$, and lowest oil yields were obtained at roasting temperature of $80^{\circ} \mathrm{C}$. The roasting temperature has been found to have a significant influence on oil yield as reported by $[19,20]$. As roasting temperature increases, oil yield also increases until the roasting temperature attained $110^{\circ} \mathrm{C}$ and then decreases, prolonged roasting temperatures above $110^{\circ} \mathrm{C}$ will not improve the oil yield as there was vapourization and volatilization of the oil, a similar finding was reported by [21 ]. At higher roasting temperatures, there is a faster rate of protein coagulation and viscosity reduction which leads to increased oil yield; while at higher roasting temperatures a substantial moisture loss was noticed which leads to hardening of samples and consequent decreased the oil yield. Oil flow is inversely proportional to the kinematic viscosity which decreases with increase in roasting temperature, thus increase in the ability of the oil to flow [22]. Also, as moisture content increases from 6 to $10 \%$, the oil yield decreases. This indicates that increased oil yield was obtained at a low moisture content of $6 \%$. The temperature and moisture content interaction was found to be more prominent than other interacting variables, this is in agreement with the findings of [23 ].

Decreased in moisture content showed a substantial improvement in oil recovery up to $6 \%$ wet basis. However, further increase in moisture content up to $10 \%$ led to a declined in the oil yield. This could be attributed to the fact that moisture addition assists in reaching the saturation point of the particles sooner during oil expression. However, when there is excess moisture, the liquid phase bears the entire load and because it is incompressible and exerts no pressure on the castor oil particles, there is a decrease in oil yield [24]. Therefore, the optimum moisture content for castor oil was found to be $6 \%$ wet basis for which an increase in moisture content causes a decline in oil yield. This trend conforms to findings of [25] on groundnut and sheanut [26].

Table 3: Response surface modified quadratic model of castor oil yield(ANOVA)

\begin{tabular}{|c|c|c|c|c|c|c|}
\hline Source & $\begin{array}{l}\text { Sum of } \\
\text { Squares }\end{array}$ & DF & $\begin{array}{l}\text { Mean } \\
\text { Square }\end{array}$ & $\begin{array}{l}\mathrm{F} \\
\text { Value }\end{array}$ & Prob $>F$ & \\
\hline Model & 202.311 & 7 & 28.902 & 81.821 & $<0.0001$ & \\
\hline A & 0 & 1 & 0 & 0 & 1.0000 & Not-significant \\
\hline $\mathrm{B}$ & 152.471 & 1 & 152.471 & 431.646 & $<0.0001$ & Significant \\
\hline $\mathrm{C}$ & 32.029 & 1 & 32.029 & 90.676 & $<0.0001$ & Significant \\
\hline $\mathrm{B}^{2}$ & 3.400 & 1 & 3.400 & 9.625 & 0.0091 & Significant \\
\hline $\mathrm{C}^{2}$ & 1.289 & 1 & 1.289 & 3.649 & 0.0803 & Not-significant \\
\hline $\mathrm{AC}$ & 2 & 1 & 2 & 5.662 & 0.0348 & Significant \\
\hline $\mathrm{BC}$ & 4.5 & 1 & 4.5 & 12.740 & 0.0039 & Significant \\
\hline Residual & 4.239 & 12 & 0.353 & & & \\
\hline Lack of Fit & 4.239 & 7 & 0.606 & & & \\
\hline Pure Error & 0 & 5 & 0 & & & \\
\hline Cor. Total & 206.550 & 19 & & & & \\
\hline
\end{tabular}

Applied Pressure $=\mathrm{A}$, Moisture content $=\mathrm{B}$, Roasting temperature $=\mathrm{C}, \mathrm{R}^{2}=0.9795, \mathrm{Adj} . \mathrm{R}^{2}=0.9675$ and Pred. $R^{2}$ $=0.9060$, Std. Dev $=0.59$, Mean $=24.15$, C.V. $=2.46$, PRESS $=19.42$

\subsection{Effect of Operating Parameters on Energy Use}

The regression analysis of the effect of operating parameters on energy use is presented in Table 4. The F-value of 144.53 with very low probability value for the model $(\mathrm{p}<0.0001)$ indicated the high significance of the fitted model. The value of the adjusted coefficient of determination indicates that a proportion of variability $(98.55 \%)$ in the response variable is attributable to the operating parameters and small portion of variability $(1.45 \%)$ in the energy used is due to other uncontrollable factors. The high value of $R^{2}(0.9924)$ is an indication that the fitted model can be used for prediction with reasonable precision as posited by[27]. Figure 4 shows the interactions between operating variables and energy use.

Equation 25 shows that the positive model terms in the equation represent a direct relationship between operating parameters and interactions with energy used, while the negative terms represent an inverse relationship between them. It was observed that moisture content have a direct relationship with energy used. Increase in moisture content leads to increase in energy used. Also, it was found that moisture content is the most important factor affecting energy used from combined castor seed roaster and oil expeller.

Table 4: Response surface modified cubic model of energy use (ANOVA) 


\begin{tabular}{|c|c|c|c|c|c|c|}
\hline Source & $\begin{array}{l}\text { Sum of } \\
\text { Squares }\end{array}$ & DF & $\begin{array}{l}\text { Mean } \\
\text { Square }\end{array}$ & $\begin{array}{l}\mathbf{F} \\
\text { Value } \\
\end{array}$ & Prob $>$ F & \\
\hline Model & 52735.4 & 9 & 5859.488 & 144.535 & $<0.0001$ & \\
\hline A & 1.525 & 1 & 1.525 & 0.038 & 0.8501 & \\
\hline B & 786.957 & 1 & 786.957 & 19.412 & 0.0013 & Significant \\
\hline $\mathrm{C}$ & 0 & 1 & 0 & 0 & 1.0000 & \\
\hline $\mathrm{A}^{2}$ & 220.706 & 1 & 220.706 & 5.444 & 0.0418 & Significant \\
\hline $\mathrm{B}^{2}$ & 388.234 & 1 & 388.234 & 9.576 & 0.0114 & Significant \\
\hline$C^{2}$ & 401.608 & 1 & 401.608 & 9.906 & 0.0104 & Significant \\
\hline $\mathrm{AB}$ & 1352 & 1 & 1352 & 33.349 & 0.0002 & Significant \\
\hline $\mathrm{A}^{3}$ & 1321.882 & 1 & 1321.882 & 32.607 & 0.0002 & Significant \\
\hline $\mathrm{B}^{3}$ & 1224 & 1 & 1224 & 30.192 & 0.0003 & Significant \\
\hline Residual & 405.404 & 10 & 40.540 & & & \\
\hline Lack of Fit & 405.404 & 5 & 81.081 & & & \\
\hline Pure Error & 0.000 & 5 & 0.000 & & & \\
\hline Cor Total & 53140.800 & 19 & & & & \\
\hline
\end{tabular}

Pressure $=\mathrm{A}$, Moisture content $=\mathrm{B}$, Roasting temperature $=\mathrm{C}$, Std. Dev. $=6.37, \mathrm{R}$ Squared $=0.9924$, Mean $=$ 654.40, Adj. R-Squared $=0.9855$, C.V. $=0.97$, Pred. R-Squared $=0.6534$, PRESS $=18419.85$, Adeq. Precision $=$ 39.092

The second-order multiple regression models predicting the energy use is presented in Equation 25 .

$Y_{4}=-3835.64440+110.33860 \mathrm{~A}+1771.69214 \mathrm{~B}-23.19473 \mathrm{C}-4.95611 \mathrm{~A}^{2}-$ $215.40263 \mathrm{~B}^{2}+0.11597 \mathrm{C}^{2}+0.65000 \mathrm{AB}+0.070667 \mathrm{~A}^{3}+8.50000 \mathrm{~B}^{3}$

Where:- $\mathrm{Y}_{4}$ is predicted energy used; $\mathrm{A}, \mathrm{B}$ and $\mathrm{C}$ are applied pressure, moisture content and roasting temperature, respectively.
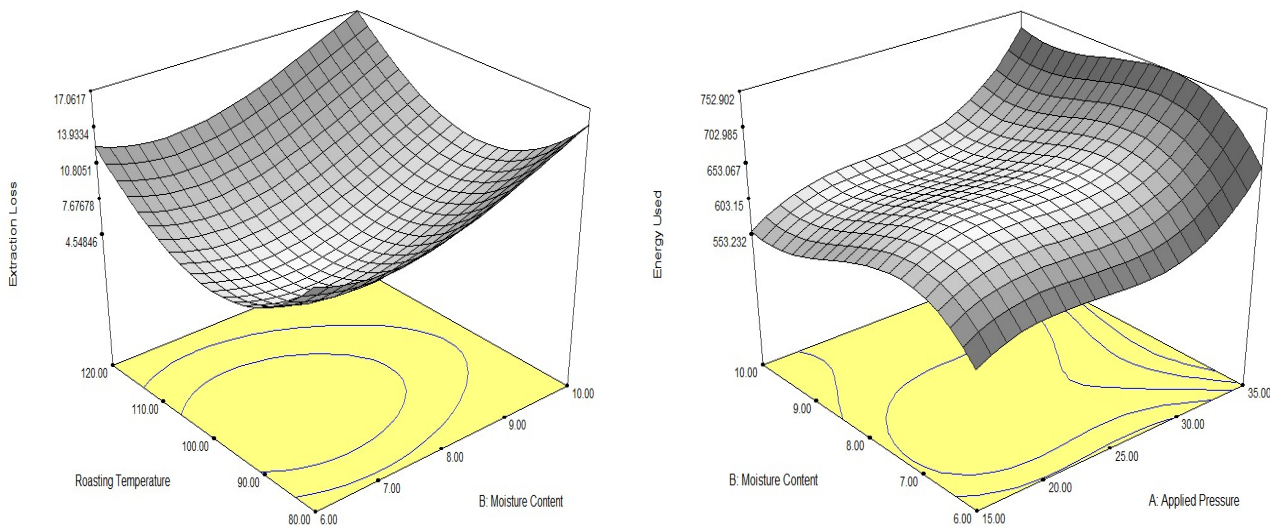

Figure 4: Response surface plot showing the effect of operating parameters on Energy use

\subsection{Optimum Conditions and Validation of Predicted Model}

The optimum conditions of the operating parameters for the oil yield were obtained at $15 \mathrm{MPa}, 6 \%$ moisture content and roasting temperature of $85.96^{\circ} \mathrm{C}$ which gave a corresponding oil yield of $32.60 \%$. Experimental oil yield was found to be $32.47 \%$ while predicted oil yield was $32.60 \%$. The percentage error was calculated to be 0.39 which confirmed the validity of the model. The result obtained was similar to [21] who reported experimental castor oil yield of $25.77 \%$ and predicted oil yield of $26.00 \%$ at a percentage error of 0.88 for the same seeds. Figure 5 shows a linear patterned graph of the model which clearly indicates that the predicted values of the oil expression efficiency can be established based on the values of applied pressure, moisture content and roasting temperature. The graph shows a high positive correlation between the actual and predicted values as reported by [28].

The predicted values were compared with experimental values and the two values were used to evaluate the percentage error which was falls within acceptable range of model fitness as reported by [21] as shown in Table 5.The test shows that there is no significant difference between the predicted and experimental values and the 
linear pattern of the graph (Figure 5). The plots of the observed versus the predicted values in the regression model is a clear indication, that the predicted values of the response variables can be established based on the values of applied pressure, moisture content and roasting temperature, hence provides a good fit for the models as reported by $[28]$.

Table 5: Validation between the predicted and experimental value

\begin{tabular}{llllllll}
\hline & \multicolumn{2}{c}{ Operating parameters } & \multicolumn{3}{c}{ Responses } \\
\cline { 2 - 7 } & $\begin{array}{l}\text { Applied } \\
\text { Pressure } \\
(\mathrm{MPa})\end{array}$ & $\begin{array}{l}\text { Moisture } \\
\text { Content } \\
(\%)\end{array}$ & $\begin{array}{l}\text { Heating } \\
\text { Temp. } \\
\left({ }^{\circ} \mathrm{C}\right)\end{array}$ & $\begin{array}{l}\text { Oil } \\
\text { Yield } \\
(\%)\end{array}$ & $\begin{array}{l}\text { Expression } \\
\text { efficiency }(\%)\end{array}$ & $\begin{array}{l}\text { Expression } \\
\text { loss } \\
(\%)\end{array}$ & $\begin{array}{l}\text { Energy } \\
\text { Used (W) }\end{array}$ \\
\hline & & & & & & & \\
Predicted & 15.00 & 6.00 & 85.96 & 32.60 & 72.40 & 0.23 & 576.10 \\
Experimental & 15.00 & 6.00 & 85.96 & 32.47 & 72.25 & 0.22 & 576.00 \\
Error (\%) & & & & 0.39 & 0.21 & 4.35 & 0.017 \\
\hline
\end{tabular}
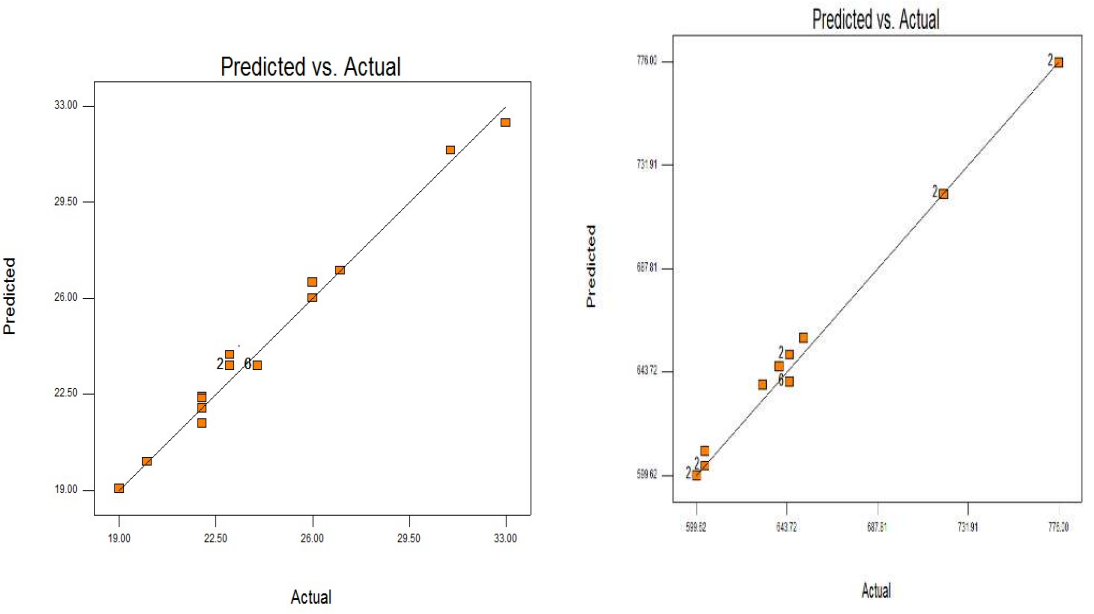

Figure 5: Predicted vs Actual Oil Yield and Energy Use

\subsection{Conclusion}

A combined castor seeds roaster-oil expeller was designed, developed and evaluated in terms of oil yield, energy use, expression efficiency and expression losses. The moisture content, roasting temperature and applied pressure of the seeds were varied. The optimum conditions of the operating parameters for the oil yield were obtained at 15 $\mathrm{MPa}, 6 \%$ moisture content and roasting temperature of $85.96^{\circ} \mathrm{C}$ which gave a corresponding oil yield of $32.60 \%$, $72.38 \%$ expression efficiency, 576.1 Watts energy usage at $99 \%$ desirability. Mathematical models were generated with higher coefficients of determinations for predicting oil yield, expression efficiency, expression loss and energy used and have satisfactory validation results.

\section{References}

[1] Onyechie, C. P., Obuka, S. P. N., Okpala, C., Oriah, N. v. and Igwegbe, A. C. 2014. Design Enhancement Evaluation of a Castor Seed Shelling Machine. Journal of Scientific Research \& Reports 3(7): 924-938, 2014; Article no. JSRR.2014.004

[2] Ogunlade, C. A. and Aremu, A. K. 2020. Modeling and optimisation of oil recovery and throughput capacity in mechanically expressing oil from African oil bean (Pentaclethra macrophylla Benth) kernels. Journal of Food Science and Technology, Springer Science. 57: 4022 - 4031. https://doi.org/10.1007/s13197-020-04435-0. http://link.springer.com/article/10.1007/s13197-02004435-0

[3] Ibrahim, A. and Onwualu, A. P. 2005. Technology for extraction of oil bearing agricultural products. Journal of Agricultural Engineering and Technology (JAET). 13:.58-70.

[4] Ogunlade, C. A. and Aremu, A. K. 2019. Influence of Processing Conditions on Yield and Quality of Mechanically Expressed African Oil Bean (Pentaclethra macrophylla Benth) Kernels: A Response Surface Approach. Journal of Food Process Engineering, John Wiley. 42 (2): 1-9. https://doi.org/10.1111/jfpe.12967and https://onlinelibrary.wiley.com/doi/pdf/10.1111/jfpe.12967

[5] Aremu, A. K. and Ogunlade, C. A. 2016. Effect of operating parameters on mechanical oil expression 
from African oil bean seeds. Global Journal of Science Frontier Research: D, Agriculture and Veterinary, Vol. 16 Issue 1 Version 1.0: PP 19-26

[6] Olatunde O. B, Ajayi, E. A. and Fatukasi S. O. 2014. Design and Fabrication of Groundnut (ArachisHypogaea) Roaster cum Expeller. International Journal of Science and Technology Volume 3(3) 177-184

[7 ] Rajput, R. K. (2012). Heat and Mass Transfer. RajendraRavindra Printers Pvt, Ltd. Fifth Revised Edition. Pp. 18 - 89.

[8] Chelecha, O. P. 2003. Design and fabrication of a multi-purpose crushing machine. Unpublished. B.Eng. Project, Mechanical Engineering Department, Federal University of Technology, Akure, Nigeria.

[9] Eugene, A. A. and Theodore, B. 1996. Marks standard Handbook of Mechanical Engineers, tenth edition,

[10] Khurmi, R. S. and Gupta, J. K. 2007. A textbook of Machine Design.14thedition, Eurasian Ltd. Ram Nagar New Delhi. Pp 1230.

[11] Ojolo, S. J. Adelaja, A. O. and Sobamowo, M. G. 2012. Production of Bio-Diesel from Palm Kernel Oil and Groundnut Oil Advanced Materials Research (Volume 367) https://doi.org/10.4028/www.scientific.net/AMR.367.501

[12] Oluwole, F. A., Aviara, N. A., Umar, B. and Mohammed, A. B. 2015. Influence of variety and pretreatment on oil properties of mechanical expressed castor oil. Global Advanced Research Journal of Engineering, Technology and Innovation 4(1): 001-009.

[13] Akintunde, A.M., Ajala S.O. and Betiku, E. 2015. Optimization of bauhinia monandra seed oil extraction via artificial neural network and response surface methodology; A potential biofuel candidate. Industrial Crop and Product. 67: 387-394.

[14] Tunde-Akintunde, T. Y., Akintunde, B. O. and Igbeka, J. C. 2001. Effects of processing factors on yield and quality of mechanically expressed soybean oil. Journal of Agric.Eng. Tech., 9: 39-45.

[15] Adeeko, K. A. and Ajibola, O. O. 1990. Processing Factors Affecting Yield and Quality of Mechanically Expressed Groundnut Oil. Journal of Agricultural Engineering Research 45(1):31-43

[16] Hamzat, K. O and Clarke, B. 1993. Prediction of oil yield from groundnut using the concept of quasiequilibrium of oil yield. Journal of Agricultural Engineering Research.55:79 - 87.

[17] Willems, P., Kuipers, N. J. M., de and Haan, A. B. 2008. Hydraulic pressing of oil seeds: experimental determination and modeling of yield and pressing rates. J. Food Eng. 89: 8-16.

[18] Baryeh, E. A. 2001. Effect of palm oil processing parameters on yield. Journal of Food Engineering. 48: $1-6$.

[19] Costa, M. N., Pereira, W. E., Bruno, R. L. A., Freire, E. C., Nóbrega, M. B. M., Milani, M. and Oliveira, A. P. ( 2006). Genetic divergence on castor bean accesses and cultivars through multivariate analysis. Pesqi. Agropecu. Bras. 41:1617-1622. (In Portuguese, with English abstract.) 10.1590/S0100204X2006001100007.

[20] Martínez, M. L., Mattea, M. A. and Maestri, D. M. (2008). Pressing and supercritical carbon dioxide extraction of walnut oil; Journal of Food Engineering; 88 (3): 399-404.

[21] Olaoye J. O. and Busari, R. A. (2017). Optimization of Mechanical Expression of Castor Seeds Oil (Ricinus communis) Using Response Surface Methodology. AZOJETE, 13(6):878-887.

[22] Kagwacie, O. C. and Anozie, N. A. (1995). Effect of processing conditions on solvent extraction of oil from rubber seeds. Journal of Agricultural Technology. 3 (1), 31-40.

[23] Bargale, P. C. (1997). Mechanical oil Expression from Selected Oil Seeds under Uniaxial Compression. University of Saskatchewan, Saskatoon, Canada.

[24] Sivala, K., Bhole, N. G. and Mukherjee, R. K. (1992). Effect of moisture on rice bran oil expression. Journal of Agricultural Engineering Resources. 50, 81-91.

[25] Olajide, J. O. (2000). Process Optimization and Modelling of Oil Expression from Groundnut andSheanut Kernels. Ph.D. Thesis, Department of Agricultural Engineering, University of Ibadan, Ibadan, Nigeria.

[26] Bamgboye, A. I., Adejumo, O. I. 2008. Effects of processing parameters of Roselle seed on its oil yield. International Journal of Agricultural and Biological Engineering, 4, 82-86.

[27] Rashid, U., Farooq A., Jamil, A. and Nawaz Bhatt, H. (2010). Jatrophacurcas seed oil as a viable source for biodiesel. Pak. J. Bot vol42 (1): 575-582, 2010.

[28] Trinh, T. K. and Kang, L. S. (2010). Application of response surface methodology as an experimental design to optimize coagulation tests; Environmental Engineering Research; 15 (12):63-70 DOI: 
10.4491/ear.21010.15.2.063 